\title{
The Puzzle of European Hair, Eye, and Skin
} Color

\author{
Peter Frost \\ c/o Bernard Saladin d'Anglure, Anthropology Department, Université Laval, Quebec City, Canada \\ Email: peter frost61z@globetrotter.qc.ca
}

Received 22 January 2014; revised 23 February 2014; accepted 15 March 2014

Copyright (C) 2014 by author and Scientific Research Publishing Inc.

This work is licensed under the Creative Commons Attribution International License (CC BY).

http://creativecommons.org/licenses/by/4.0/

(c) (7) Open Access

\section{Abstract}

Europeans, particularly northern and eastern Europeans, are unusually colored. Their hair can be not only black but also brown, flaxen, golden, or red, and their eyes not only brown but also blue, gray, hazel, or green. Their skin is pale, almost like an albino's. This color scheme is more developed in women than in men and seems to have been selected for its visual properties, particularly brightness and novelty. Sexual selection is a likely cause. It favors eye-catching colors and, if strong enough, can produce a color polymorphism, i.e., whenever a visible feature becomes differently colored through mutation, the new color will spread through the population until it loses its novelty value and becomes as frequent as the original one. Such selection is consistent with 1) the many alleles for European hair and eye color; 2) the high ratio of nonsynonymous to synonymous variants; and 3) the relatively short time over which this color diversity developed. Sexual selection will target women if they outnumber men on the mate market. Among early modern humans, such imbalances resulted from 1) a low polygyny rate (because few men could provide for a second wife and her children) and 2) a high risk of early male death (because long hunting distances increased exposure to environmental hazards). Sexual selection of women was stronger at latitudes farther from the equator, where men were less polygynous and more at risk of death while hunting. It was strongest on continental steppe-tundra, where men provided for almost all family food needs by pursuing herds of reindeer and other herbivores over long distances. Although this type of environment is now fragmentary, it covered until 10,000 years ago a much larger territory - the same area where, today, hair and eyes are diversely colored and skin almost milk white.

\section{Keywords}

Brightness, Eye Color, Hair Color, Novelty, Sexual Selection, Skin Color 


\section{Introduction}

Most humans have black hair, brown eyes, and brown skin. Europeans have a different color scheme, their hair being also brown, flaxen, golden, or red, and their eyes also blue, gray, hazel, or green. Finally, their skin is pale, almost like an albino's.

How did this unusual color scheme come about? Perhaps the genetic change that lightened the skin also affected the hair and the eyes. Yet the genes are different in each case. European skin lightened mainly through the appearance of new alleles at three genes: SLC45A2, SLC24A5, and TYRP1 (Beleza et al., 2013; Canfield et al., 2014; Soejima et al., 2005; Voight et al., 2006). European hair color diversified through a proliferation of new alleles at MC1R (Box et al., 1997; Flanagan et al., 2000; Makova \& Norton, 2005; Rana et al., 1999). European eye color diversified through a proliferation of new alleles in the HERC2-OCA2 region and elsewhere (Duffy et al., 2007; Eiberg et al., 2008; Kayser et al., 2008; Liu et al., 2010; Sturm \& Frudakis, 2004; Sturm et al., 2008).

Light skin is associated with a few of the new hair and eye color alleles, particularly the ones for red hair or blue eyes. Conceivably, these alleles may be a side effect of selection for lighter skin (Duffy et al., 2004; Sturm \& Frudakis, 2004). But why would such selection increase the total number of alleles for hair and eye color, especially when so many of them have little or no effect on skin color? And why have neither red hair nor blue eyes reached fixation in any human population, even those with milk-white complexions?

The European color scheme has another puzzling aspect. It seems to result from a selection pressure that acted primarily on women and only secondarily on men:

- Hair color varies more in women than in men. Redheads are especially more frequent among women (Shekar et al., 2008).

- Eye color varies more in women than in men when both copies of the so-called blue-eye allele are present, the result being a greater diversity of female eye colors wherever blue eyes are the single most common phenotype, i.e., in northern and eastern Europe (Martinez-Cadenas et al., 2013).

- Blue eyes are associated in men with a more feminine face shape (Kleisner et al., 2010; Kleisner et al., 2013).

- In all human populations, women are paler than men after puberty. This post-pubescent lightening is due to sexual maturation and not to differences in sun exposure (Edwards \& Duntley, 1939; Edwards \& Duntley, 1949; Edwards et al., 1941; van den Berghe \& Frost, 1986). In women, lightness of skin correlates with thickness of subcutaneous fat and with 2nd to 4th digit ratio-a marker of prenatal estrogenization (Manning et al., 2004; Mazess, 1967). Admittedly, this sex difference is not greater in Europeans than in other populations, although it could not easily be otherwise, since Europeans are so close to the physiological limit of depigmentation.

While women are more diverse than men both in hair and eye color, this greater diversity came about differently in each case. With hair color, women have more of the intermediate hues because the darkest hue (black) is less easily expressed (Shekar et al., 2008). With eye color, women have more of the intermediate hues because the lightest hue (blue) is less easily expressed (Martinez-Cadenas et al., 2013).

In sum, European hair and eye color diversified through a selection pressure that acted on different genes via different pigmentary changes. The common denominator seems to be the creation of new visual stimuli on or near the face-the focus of visual attention.

\section{Sexual Selection?}

What type of selection pressure would make a facial feature more colorful in one sex than in the other? The likeliest type is sexual selection, which occurs when the mate market has too many of one sex and too few of the other. The more one must compete for a mate, the more one must vie for attention, and the more success requires eye-catching qualities (Darwin, 1936: pp. 567-924; Emlen \& Oring, 1977). This is the logic of advertising. "Visual merchandising" matters most in saturated markets that offer too many interesting choices among products of equal quality (Lea-Greenwood, 1998; Oakley, 1990).

One way to catch the eye is through bright or novel colors. Brightness keeps a color in memory longer, and novelty focuses attention on a color longer (Brockmole \& Boot, 2009; Maan \& Cummings, 2009). Significantly, perhaps, hair and eye colors are not only more diverse in Europe but also brighter. Hair is carrot red but not beet red. Eyes are sky blue but not navy blue.

Other ways to catch the eye include enlargement of secondary sexual characteristics and enhancement of fa- 
cial features. The effect is to "boost the signal" from visual features that are used either for sex identification or for communication and personal identification (Manning, 1972: pp. 47-49).

\section{Frequency-Dependent Sexual Selection and Color Polymorphism}

If strong enough, sexual selection may create a color polymorphism. Whenever a visible feature becomes differently colored through mutation, the new color will spread through the population until it loses its novelty value and becomes as frequent as the original one. The resulting equilibrium will last until another color variant appears, and the total number of colors will thus grow over time. Such polymorphisms are known in a number of animal species, notably guppies, lizards, and various insects (Anderson, 1969; Brooks, 2002; Eakley \& Houde, 2004; Endler, 1980; Farr, 1980; Grant et al., 1974; Hampton et al., 2009; Healey et al., 2008; Hughes et al., 1999; Hughes et al., 2005; Kokko et al., 2007; Muggleton, 1979; Olendorf et al., 2006; Simchuk, 2001; Sinnock, 1970).

Humans, too, tend to prefer novel colors when choosing mates. In one study, men were shown pictures of attractive women and asked to choose the one they most wanted to marry. One series had equal numbers of brunettes and blondes, a second series 1 brunette for every 5 blondes, and a third 1 brunette for every 11 blondes. It turned out that the scarcer the brunettes were in a series, the likelier any one brunette would be chosen (Thelen, 1983). Another study likewise found that Maxim cover girls were much more often light blonde or dark brown than the usual dark blonde or light brown of real life (Anon, 2008). This novelty effect may be seen in sales of home interior colors over the past half-century: preference for one paint color rises until satiated, then falls and yields to preference for another (Stansfield \& Whitfield, 2005).

Preference for novel colors, together with sufficiently strong sexual selection, may have caused European hair and eye color to diversify. At the main hair-color gene, $M C 1 R$, Europeans have 11 nonsynonymous alleles versus 5 for Asians and 1 for Africans (Harding et al., 2000). The actual disparity is even greater because the Asian alleles produce similar phenotypes. Europeans likewise have many alleles for eye color within the HERC2OCA2 region (Liu et al., 2010). Contrary to widespread belief, brown eyes are not truly dominant and blue eyes are not truly recessive. A single copy of the blue-eye allele usually produces an intermediate hue, like green or hazel, and even two copies will not always produce blue eyes (Branicki et al., 2009; Eiberg et al., 2008; Martinez-Cadenas et al., 2013).

These new hair and eye colors cannot be older than the arrival of modern humans in Europe around 40,000 years ago. Such a narrow timeframe argues for some kind of selection, rather than relaxation of selection and accumulation of non-adaptive mutations. The second scenario requires close to a million years to produce the current variability of hair and eye color, including approximately 80,000 years for today's prevalence of red hair alone (Harding et al., 2000; Templeton, 2002).

\section{Latitudinal Variation in the Intensity of Sexual Selection}

If ancestral Europeans gained new hair and eye colors through sexual selection, something must have skewed the ratio of men to women on the mate market. Such an imbalance can arise if the risk of early death differs by sex or if one sex tends to mate more often than the other one (Darwin, 1936: pp. 573-578; Emlen \& Oring, 1977).

In most mammalian species, the males are the ones with more mates because they can return to the mate market sooner after impregnation. In contrast, the females are unavailable during pregnancy, lactation, and infant care. This pattern applies less to our species. Because humans have a longer infancy, the male is better able to increase his reproductive fitness by providing for his mate and her offspring. The more he becomes a provider, the more each act of mating will end up costing him and the longer he will stay off the mate market.

In early human societies, i.e., hunter-gatherers and simple farming peoples, male provisioning varied with latitude. It was minimal in the tropics because women could gather or grow food year-round on their own. Polygyny was thus common, being limited not so much by a man's capacity to be a provider as by his ability to compete against rival males (van den Berghe, 1979: pp. 65-67).

Women were less self-reliant beyond the tropics. During winter, they could no longer gather or grow food and depended on meat from their hunting spouses. This dependence increased with longer winters at higher latitudes (Hoffecker, 2002: p. 8; Kelly, 1995: pp. 262-270). Whereas women supplied 40\% - 55\% of all food consumed by hunter-gatherers below $40^{\circ} \mathrm{N}$, the proportion fell to less than $10 \%$ above $60^{\circ} \mathrm{N}$ (Martin, 1974: pp. 16-18). At those latitudes, only a very able hunter could take a second wife (Kjellström, 1973: p. 118). 
Higher latitudes meant not just fewer men on the mate market but also fewer men altogether. Because women could not supply as much food and because the land supported a lower density of wildlife, men had to hunt for longer periods and over longer distances, with the result that more of them died from falls, drowning, starvation, and cold exposure (Burch Jr., 1972: pp. 339-368, 347, 349-350; Hoffecker, 2002: pp. 8-9; Kelly, 1995: pp. 128-132; Krupnik, 1985). Women thus faced a more competitive mate market and stronger pressures of sexual selection. This was especially so on the continental steppe-tundra of the sub-Arctic, where almost all food came from hunting of reindeer and other migratory game (Hoffecker, 2002: pp. 7-12; Schild, 1976).

Although continental steppe-tundra is now confined to parts of northeastern Siberia, Alaska, and the Canadian Arctic, it was much more extensive during the last ice age 25,000 to 10,000 years ago, when it formed a broad Eurasian zone that stretched across the plains of northern and eastern Europe and into northern Asia (see Figure 1). This zone was continuously inhabited only at its western end. The climate was milder there because the Scandinavian icecap had pushed the steppe-tundra south of the $50^{\circ} \mathrm{N}$ parallel and because the nearby Atlantic Ocean provided warmth and moisture (Butzer, 1971: pp. 144, 463; Hoffecker, 2002: pp. 3, 17). These conditions favored a lush growth of grasses, mosses, lichens, and low shrubs, which supported large herds of herbivores and, in turn, a large human population.

East of the Urals, this zone swung north into colder, drier territory. The Asian steppe-tundra was not only farther north but also farther from the Atlantic's moderating influence. Its human population was thus smaller and prone to extinction over large areas, particularly during the glacial maximum (Goebel, 1999; Graf, 2009a; Graf, 2009b). This view is supported by analysis of DNA retrieved from human remains dated to 24,000 BP and 17,000 BP in south-central Siberia. Although the DNA shows strong affinities with present-day Europeans and Amerindians, the affinity is more distant with present-day Siberians, who seem to be largely the product of repeopling from the south near the end of the last ice age (Maanasa et al., 2013).

The European steppe-tundra was thus a singularity among the many environments that modern humans entered while spreading out from Africa during the Paleolithic. Food was abundant but accessible only to males of hunting age, whose ranks were continually thinned by hunting-related mortality. The resulting surplus of mateable females, combined with the high cost of polygyny, would have greatly intensified sexual selection of women.

This region, essentially the plains of northern and eastern Europe, is today a singularity on the world map of human physical variation. If we add Scandinavia, which was repeopled from these plains after the last ice age, we have the same region where the skin is whitest and the hair and eyes most diversely colored (Frost, 2006; Frost, 2008).

This geographic singularity stands out even more further back in time. Ancient DNA from two Mesolithic hunter-gatherers, one from Luxembourg (8000 BP) and the other from Spain (7000 BP), reveals that both had brown skin even though they postdate the timeframe when European skin became white (Beleza et al., 2013; Canfield et al., 2014; Lazaridis et al., 2013; Olalde et al., 2014; see Table 1). On the other hand, both had non-brown eyes (Lazaridis et al., 2013; Olalde et al., 2014). It seems that these European color traits evolved initially within part of Europe - the plains of the north and east-and only later spread outward to the rest of the continent and elsewhere, perhaps through a succession of demographic expansions. It also seems that the changes to hair, eye, and skin color were not simultaneous. Diversification of eye color preceded diversification of hair color and whitening of the skin.

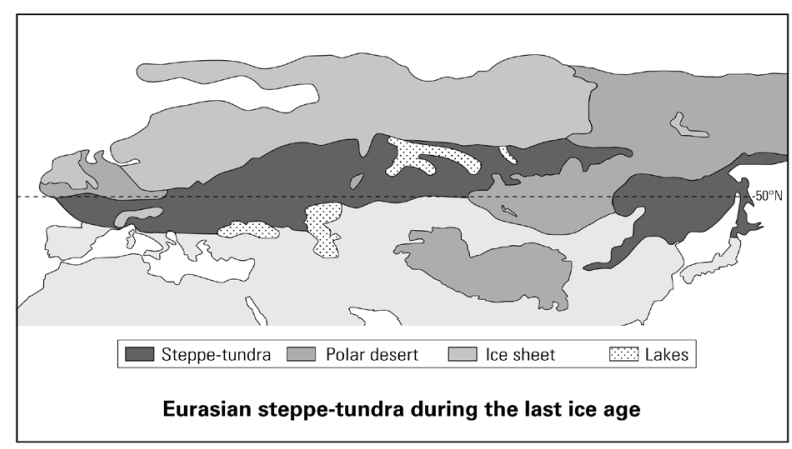

Figure 1. Eurasian steppe-tundra during the last ice age (Ray \& Adams, 2001). 
Table 1. Evolution of European color traits.

\begin{tabular}{lll}
\hline Gene & Estimated time of origin of European alleles & Resulting phenotype \\
\hline SLC45A2 & $\begin{array}{l}\text { 19,000 - 11,000 BP (Beleza et al., 2013) } \\
\text { S11,000 BP (Soejima et al., 2005) }\end{array}$ & Lighter skin \\
& $19,200-7600$ BP (Canfield et al., 2014) & Lighter skin \\
& $\approx 19,000-11,000$ BP (Beleza et al., 2013) & \\
TYRP1 & $12,000-3000$ BP (Norton \& Hammer, 2007) & \\
HERC2-OCA2 & $\approx 10,000$ - 6000 BP (Eiberg et al., 2008) & Lighter skin \\
& $\begin{array}{l}\text { some time before 8000 BP (Lazaridis et al., 2013) } \\
\text { some time before 7000 BP (Olalde et al., 2014) }\end{array}$ & New eye colors \\
MC1R & no dating yet & New hair colors \\
\hline
\end{tabular}

\section{Sex Linkage?}

If hair- and eye-color diversity is due to sexual selection of women, it should be expressed more in women than in men. There should be sex linkage. Initially, such selection would have acted on whatever alleles were available, these being for the most part not sex-linked. Over time, there would have arisen new alleles that produce non-black hair and non-brown eyes to a greater degree in women, and these alleles would have gradually replaced the older ones. This process would have admittedly been limited by the narrow timeframe of intense sexual selection, i.e., the last ice age.

The new alleles show some sex linkage. Girls are lighter-haired than boys after puberty (Steggerda, 1941). During adulthood, blond hair darkens with age more slowly in women than in men (Olivier, 1960: p. 74). A twin study has confirmed that hair is lighter in women than in men and that women show greater variation in hair color (Shekar et al., 2008). Finally, an unpublished digit ratio study indicates that prenatal exposure to estrogen is higher in individuals with non-black hair or non-brown eyes (Mather et al., unpublished).

If prenatal estrogen mediates this sex linkage, one result may be a more feminine face shape if eyes are not brown. This was the unintended finding of two Czech studies where the participants were asked to rate male and female facial photos (Kleisner et al., 2010; Kleisner et al., 2013). The initial finding was that brown-eyed men were perceived as more dominant than blue-eyed men. When, as a control, the brown-eyed men were photoshopped to look blue-eyed, they were still rated as more dominant. Careful examination revealed that they had more masculine faces with broader and more massive chins, broader mouths, larger noses, larger eyebrows, and closer-set eyes. The blue-eyed men had smaller and sharper chins, narrower mouths, smaller noses, and a greater distance between the eyes.

Only the male faces showed this relationship between eye color and face shape, perhaps because female face shape is hormonally overdetermined, i.e., all girls are exposed to enough estrogen in the womb to feminize their faces, but only blue-eyed boys reach this level of exposure. Could it be that eye color correlated with face shape because some of the photos showed partly Jewish or Roma men with darker eyes and a different face shape? If so, the brown-eyed men should have been more variable in face shape, yet they were not. This explanation also fails to explain why blue eyes correlated with facial feminization in men but not in women.

We see a similar pattern with eye color and shyness. In preschool boys, shyness is more strongly associated with blue eyes than with brown eyes. This association is absent in preschool girls (Coplan et al., 1998).

\section{Other Physical Legacies of Strong Sexual Selection}

If intense sexual selection of women had created the palette of European hair and eye colors, it could have caused other physical characteristics to assume a specific color or form. There may thus be other legacies of this episode of human evolution.

\subsection{Whitening of the Skin}

One legacy may be the extreme loss of skin pigment we see in northern and eastern Europe-the same region where hair and eye color have diversified. This whitening is often said to be an adaptation to lower levels of so- 
lar UV at higher latitudes and under cloudier skies. With less need for UV protection, the skin no longer had to be so dark. Alternatively, the skin lightened so that more UV could pass through it for vitamin-D synthesis (Robins, 1991: pp. 187-212).

This kind of explanation fails for two reasons. First, ground-level solar UV is equally low across Europe, northern Asia, and North America at latitudes above $47^{\circ} \mathrm{N}$ (Jablonski \& Chaplin, 2000: pp. 71, 76). Yet it is only in Europe that we see extreme whitening of the skin. Second, according to a study of the genes responsible, Europeans became white-skinned during the last ice age and long after their ancestors had entered Europe some 40,000 years ago (Beleza et al., 2013; Canfield et al., 2014; Norton \& Hammer, 2007; see Table 1). “The implication is that our European ancestors were brown-skinned for tens of thousands of years” (Gibbons, 2007). If white skin is an adaptation to lower levels of solar UV, ancestral Europeans should have begun to whiten once they had reached the more northerly and cloudier environments of Europe.

But if the cause had been sexual selection, why did the skin become white instead of more diversely colored, like the hair and the eyes? It may be that men tended to choose lighter-skinned women from the outset because paleness is widely viewed as a female norm. In all human populations, women are the "fair sex", their skin having less melanin and less peripheral blood flow. Male skin is brown and ruddy by comparison (Edwards \& Duntley, 1939; Edwards \& Duntley, 1949; Edwards et al., 1941; Frost, 1988; Frost, 2010; Manning et al., 2004; Mazess, 1967; van den Berghe \& Frost, 1986). The human mind thus seems predisposed to distinguish men from women by their skin coloring, even more so than by their face shape, as shown by the ability of subjects to tell whether a face is male or female even if the image is blurred and differs only in color (Tarr et al., 2001). The gender cues are hue and luminosity. Besides having a less brown and less ruddy complexion, women also display higher luminous contrast between their facial skin and their lips and eyes (Dupuis-Roy et al., 2009). This may be why so many cultures have independently developed cosmetics to lighten facial skin while darkening the lips and the eye area (Russell, 2009; Russell, 2010). There is likewise a cross-cultural tendency to see fairerskinned women as more feminine and to prefer them as mates, at least in traditional cultures (van den Berghe \& Frost, 1986).

Thus, among ancestral Europeans, and under conditions of intense sexual selection, darker women would have been disadvantaged on the mate market except when scarce enough to benefit from the novelty effect. Over time, mean skin color would have steadily lightened until sexual selection for lighter female skin had encountered equally strong natural selection for darker skin (to protect against solar UV) or a physiological limit to further loss of pigmentation.

If Europeans became white because of stronger sexual selection for lightness of female skin, one might expect them to show a larger sex difference in skin color. Actually, this sex difference is largest in people with medium-colored skin (Frost, 2007; Madrigal \& Kelly, 2006). There may be a ceiling effect in very light-skinned people, i.e., female skin color cannot diverge as much from male skin color because both are already close to the physiological limit of depigmentation.

\subsection{Face and Body Morphology}

Another legacy may be face shape. In Europeans, the face seems to have assumed its present form through a selection pressure that acted primarily on women (Liberton et al., 2009). As with skin color, selection for more feminine-looking women would have spilled over on to men as well, causing the population as a whole to have more feminine faces.

Finally, this intensification of sexual selection may have affected secondary sexual characteristics that have long assumed different forms in men and women. In such cases, the existing sexual dimorphism should be enhanced. This may be why women of European descent have wider hips, narrower waists, and thicker subcutaneous fat than do women of other origins (Choi \& Trotter, 1970; Gasperino, 1996; Hrdlicka, 1898; Meredith \& Spurgeon, 1980; Nelson \& Nelson, 1986).

\section{Conclusion}

Sexual selection best explains the puzzle of European hair, eye, and skin color. Within the same geographic range, and long after modern humans had arrived in Europe, all three color traits changed greatly at an apparently fast rate. Although hair color and eye color both underwent a similar diversification that produced similarly conspicuous hues, this process occurred at separate genes and in different ways. The new hues were also on or 
near the face, which is the focus of visual attention. Finally, this evolutionary change went farther in women than in men. It seems, then, that the European color scheme was selected for its visual qualities in a context where women were the observed and men the observers.

Such a context is consistent with the European steppe-tundra of the last ice age, where men were scarce on the mate market because of the high cost of polygyny and the high mortality due to long hunting distances. There was thus selection for visible female features that catch male attention, either through display of bright or novel colors or through enhancement of existing sexual dimorphisms.

\section{References}

Anderson, W. W. (1969). Polymorphism Resulting from the Mating Advantage of Rare Male Genotypes. Proceedings of the National Academy of Sciences USA, 64, 190-197. http://dx.doi.org/10.1073/pnas.64.1.190

Anon (2008). Maxim’s Audience Prefers Brunettes; Distribution Is Bimodal. Gene Expression, July 6. http://www.gnxp.com/blog/2008/07/maxims-audience-prefers-brunettes.php

Beleza, S., Murias dos Santos, A., McEvoy, B., Alves, I., Martinho, C., Cameron, E., Shriver, M. D., Parra, E. J., \& Rocha, J. (2013). The Timing of Pigmentation Lightening in Europeans. Molecular Biology and Evolution, 30, 24-35. http://dx.doi.org/10.1093/molbev/mss207

Box, N. F., Wyeth, J. R., O’Gorman, L. E., Martin, N. G., \& Sturm, R. A. (1997). Characterization of Melanocyte Stimulating Hormone Receptor Variant Alleles in Twins with Red Hair. Human Molecular Genetics, 6, 1891-1897. http://dx.doi.org/10.1093/hmg/6.11.1891

Branicki, W., Brudnik, U., \& Wojas-Pelc, A. (2009). Interactions between HERC2, OCA2 and MC1R May Influence Human Pigmentation Phenotype. Annals of Human Genetics, 73, 160-170. http://dx.doi.org/10.1111/j.1469-1809.2009.00504.X

Brockmole, J. R., \& Boot, W. R. (2009). Should I Stay or Should I Go? Attentional Disengagement from Visually Unique and Unexpected Items at Fixation. Journal of Experimental Psychology: Human Perception, 35, 808-815.

Brooks, R. (2002).Variation in Female Mate Choice within Guppy Populations: Population Divergence, Multiple Ornaments and the Maintenance of Polymorphism. Genetica, 116, 343-358. http://dx.doi.org/10.1023/A:1021228308636

Burch Jr., E. S. (1972). The Caribou/Wild Reindeer as a Human Resource. American Antiquity, 37, 339-368. http://dx.doi.org/10.2307/278435

Butzer, K. W. (1971). Environment and Archeology. Aldine: Chicago.

Canfield, V. A., Berg, A., Peckins, S., Wentzel, S. M., Ang, K. C., Oppenheimer, S., \& Cheng, K. C. (2014). Molecular Phylogeography of a Human Autosomal Skin Color Locus under Natural Selection. G3, 3, 2059-2067.

Choi, S. C., \& Trotter, M. A. (1970). Statistical Study of the Multivariate Structure and Race-Sex Differences of American White and Negro Fetal Skeletons. American Journal of Physical Anthropology, 33, 307-312. http://dx.doi.org/10.1002/ajpa.1330330304

Coplan, R., Coleman, B., \& Rubin, K. (1998). Shyness and Little Boy Blue: Iris Pigmentation, Gender, and Social Wariness in Preschoolers. Developmental Psychobiology, 32, 37-44. http://dx.doi.org/10.1002/(SICI)1098-2302(199801)32:1<37::AID-DEV4>3.0.CO;2-U

Darwin, C. (1936 [1888]). The Descent of Man and Selection in Relation to Sex (2nd ed.). New York: Random House.

Duffy, D. L., Box, N. F., Chen, W., Palmer, J. S., Montgomery, G. W., James, M. R., Hayward, N. K., Martin, N. G., \& Sturm, R. A. (2004). Interactive Effects of MC1R and OCA2 on Melanoma Risk Phenotypes. Human Molecular Genetics, 13, 447-461. http://dx.doi.org/10.1093/hmg/ddh043

Duffy, D. L., Montgomery, G. W., Chen, W., Zhao, Z. Z., Le, L., James, M. R., Hayward, N. K., Martin, N. G., \& Sturm, R. A. (2007). A Three-Single-Nucleotide Polymorphism Haplotype in Intron 1 of OCA2 Explains Most Human Eye-Color Variation. American Journal of Human Genetics, 80, 241-252. http://dx.doi.org/10.1086/510885

Dupuis-Roy, N., Fortin, I., Fiset, D., \& Gosselin, F. (2009). Uncovering Gender Discrimination Cues in a Realistic Setting. Journal of Vision, 9, 10.1-10.8.

Eakley, A. L., \& Houde, A. E. (2004). Possible Role of Female Discrimination against "Redundant” Males in the Evolution of Colour Pattern Polymorphism in Guppies. Proceedings of the Royal Society of London B: Biological Sciences, 271, S299-S301. http://dx.doi.org/10.1098/rsbl.2004.0165

Edwards, E. A., \& Duntley, S. Q. (1939). The Pigments and Color of Living Human Skin. American Journal of Anatomy, 65, 1-33. http://dx.doi.org/10.1002/aja.1000650102

Edwards, E. A., \& Duntley, S. Q. (1949). Cutaneous Vascular Changes in Women in Reference to the Menstrual Cycle and Ovariectomy. American Journal of Obstetrics \& Gynecology, 57, 501-509.

Edwards, E. A., Hamilton, J. B., Duntley, S. Q., \& Hubert, G. (1941). Cutaneous Vascular and Pigmentary Changes in Castrate and Eunuchoid Men. Endocrinology, 28, 119-128. http://dx.doi.org/10.1210/endo-28-1-119 
Eiberg, H., Troelsen, J., Nielsen, M., Mikkelsen, A., Mengel-From, J., Kjaer, K. W., \& Hansen, L. (2008). Blue Eye Color in Humans May Be Caused by a Perfectly Associated Founder Mutation in a Regulatory Element Located within the HERC2 Gene Inhibiting OCA2 Expression. Human Genetics, 123, 177-187. http://dx.doi.org/10.1007/s00439-007-0460-x

Emlen, S. T., \& Oring, L. W. (1977). Ecology, Sexual Selection, and the Evolution of Mating Systems. Science, 197, 215223. http://dx.doi.org/10.1126/science.327542

Endler, J. A. (1980). Natural Selection on Color Patterns in Poecilia reticulata. Evolution, 34, 76-91. http://dx.doi.org/10.2307/2408316

Farr, J. A. (1980). Social Behavior Patterns as Determinants of Reproductive Success in the Guppy Poecilia reticulata Peters (Pisces: Poeciliidae). Behaviour, 74, 38-90. http://dx.doi.org/10.1163/156853980X00311

Flanagan, N., Healy, E., Ray, A., Philips, S., Todd, C., Jackson, I. J., Birch-Machin, M. A., \& Rees, J. L. (2000). Pleiotropic Effects of the Melanocortin 1 Receptor (MC1R) Gene on Human Pigmentation. Human Molecular Genetics, 9, $2531-2537$. http://dx.doi.org/10.1093/hmg/9.17.2531

Frost, P. (1988). Human Skin Color: A Possible Relationship between Its Sexual Dimorphism and Its Social Perception. Perspectives in Biology and Medicine, 32, 38-58.

Frost, P. (2006). European Hair and Eye Color-A Case of Frequency-Dependent Sexual Selection? Evolution and Human Behavior, 27, 85-103. http://dx.doi.org/10.1016/j.evolhumbehav.2005.07.002

Frost, P. (2007). Comment on Human Skin-Color Sexual Dimorphism: A Test of the Sexual Selection Hypothesis. American Journal of Physical Anthropology, 133, 779-781. http://dx.doi.org/10.1002/ajpa.20555

Frost, P. (2008). Sexual Selection and Human Geographic Variation, Special Issue: Proceedings of the 2nd Annual Meeting of the North-Eastern Evolutionary Psychology Society. Journal of Social, Evolutionary, and Cultural Psychology, 2, 169191. http://dx.doi.org/10.1037/h0099346

Frost, P. (2010). Femmes claires, hommes foncés. Les racines oubliées du colorisme (202 p). Quebec City: Les Presses de l’Université Laval.

Gasperino, J. (1996). Ethnic Differences in Body Composition and Their Relation to Health and Disease in Women. Ethnicity \& Health, 1, 337-347. http://dx.doi.org/10.1080/13557858.1996.9961803

Gibbons, A. (2007). American Association of Physical Anthropologists Meeting: European Skin Turned Pale Only Recently, Gene Suggests. Science, 316, 364.

Goebel, T. (1999). Pleistocene Human Colonization of Siberia and Peopling of the Americas: An Ecological Approach. Evolutionary Anthropology, 8, 208-227. http://dx.doi.org/10.1002/(SICI)1520-6505(1999)8:6<208::AID-EVAN2>3.0.CO;2-M

Graf, K. E. (2009a). “The Good, the Bad, and the Ugly”: Evaluating the Radiocarbon Chronology of the Middle and Late Upper Paleolithic in the Enisei River Valley, South-Central Siberia. Journal of Archaeological Science, 36, 694-707. http://dx.doi.org/10.1016/j.jas.2008.10.014

Graf, K. E. (2009b). Modern Human Colonization of the Siberian Mammoth Steppe: A View from South-Central Siberia. In M. Camps, \& P. Chauhan (Eds.), Sourcebook of Paleolithic Transitions (pp. 484-496). Berlin: Springer Science \& Business Media. http://dx.doi.org/10.1007/978-0-387-76487-0 32

Grant, B., Snyder, A., \& Glessner, S. F. (1974). Frequency-Dependent Mate Selection in Mormoniella vitripennis. Evolution, 28, 259-264. http://dx.doi.org/10.2307/2407327

Hampton, K. J., Hughes, K. A., \& Houde, A. E. (2009). The Allure of the Distinctive: Reduced Sexual Responsiveness of Female Guppies to "Redundant” Male Colour Patterns. Ethology, 115, 475-481. http://dx.doi.org/10.1111/j.1439-0310.2009.01634.X

Harding, R. M., Healy, E., Ray, A. J., Ellis, N. S., Flanagan, N., Todd, C., Dixon, C., Sajantila, A., Jackson, I. J., BirchMachin, M. A., \& Rees, J. L. (2000). Evidence for Variable Selective Pressures at MC1R. American Journal of Human Genetics, 66, 1351-1361. http://dx.doi.org/10.1086/302863

Healey, M., Uller, T., \& Olsson, M. (2008). Variety Is the Spice of Life: Female Lizards Choose to Associate with ColourPolymorphic Male Dyads. Ethology, 114, 231-237. http://dx.doi.org/10.1111/j.1439-0310.2007.01469.x

Hoffecker, J. F. (2002). Desolate Landscapes. Ice-Age Settlement in Eastern Europe. New Brunswick: Rutgers University Press.

Hrdlicka, A. (1898). Physical Differences between White and Colored Children. American Anthropologist, 11, 347-350. http://dx.doi.org/10.1525/aa.1898.11.11.02a00020

Hughes, K. A., Du, L., Rodd, F. H., \& Reznick, D. N. (1999). Familiarity Leads to Female Mate Preference for Novel Males in the Guppy, Poecilia reticulata. Animal Behavior, 58, 907-916. http://dx.doi.org/10.1006/anbe.1999.1225

Hughes, K. A., Rodd, F. H., \& Reznick, D. N. (2005). Genetic and Environmental Effects on Secondary Sex Traits in Guppies (Poecilia reticulata). Journal of Evolutionary Biology, 18, 35-45.

http://dx.doi.org/10.1111/j.1420-9101.2004.00806.x 
Jablonski, N. G., \& Chaplin, G. (2000). The Evolution of Human Skin Coloration. Journal of Human Evolution, 39, 57-106 (p. 71, 76).

Kayser, M., Liu, F., Janssens, A. C. J. W., Rivadeneira, F., Lao, O., van Duijn, K., Vermeulen, M., Arp, P., Jhamai, M. M., van Ijcken, W. F. J., den Dunnen, J. T., Heath, S., Zelenika, D., Despriet, D. D. G., Klaver, C. C. W., Vingerling, J. R., de Jong, P. T. V. M., Hofman, A., Aulchenko, Y. S., Uitterlinden, A. G., Oostra, B. A., \& van Duijn, C. M. (2008). Three Genome-Wide Association Studies and a Linkage Analysis Identify HERC2 as a Human Iris Color Gene. American Journal of Human Genetics, 82, 411-423. http://dx.doi.org/10.1016/j.ajhg.2007.10.003

Kelly, R. L. (1995). The Foraging Spectrum. Diversity in Hunter-Gatherer Lifeways. Washington DC: Smithsonian Institution Press.

Kjellström, R. (1973). Eskimo Marriage. An Account of Traditional Eskimo Courtship and Marriage (p. 80). Lund: Nordiska Museets Handlingar.

Kleisner, K., Kocnar, T., Rubešova, A., \& Flegr, J. (2010). Eye Color Predicts but Does Not Directly Influence Perceived Dominance in Men. Personality and Individual Differences, 49, 59-64. http://dx.doi.org/10.1016/j.paid.2010.03.011

Kleisner, K., Priplatova, L., Frost, P., \& Flegr, J. (2013). Trustworthy-Looking Face Meets Brown Eyes. PLoS ONE, 8, e53285. http://dx.doi.org/10.1371/journal.pone.0053285

Kokko, H., Jennions, M. D., \& Houde, A. (2007). Evolution of Frequency-Dependent Mate Choice: Keeping Up with Fashion Trends. Proceedings of the Royal Society of London B: Biological Sciences, 274, 1317-1324. http://dx.doi.org/10.1098/rspb.2007.0043

Krupnik, I. I. (1985). The Male-Female Ratio in Certain Traditional Populations of the Siberian Arctic. Inuit Studies, 9, 115140.

Lazaridis, I., Patterson, N., Mittnik, A., Renaud, G., Mallick, S. et al. (2013). Ancient Human Genomes Suggest Three Ancestral Populations for Present-Day Europeans. BioRxiv, December 23. http://biorxiv.org/content/early/2013/12/23/001552.full-text.pdf+html

Lea-Greenwood, G. (1998). Visual Merchandising: A Neglected Area in UK Fashion Marketing? International Journal of Retail \& Distribution Management, 26, 324-329. http://dx.doi.org/10.1108/09590559810231797

Liberton, D. K., Matthes, K. A., Pereira, R., Frudakis, T., Puts, D. A., \& Shriver, M. D. (2009). Patterns of Correlation between Genetic Ancestry and Facial Features Suggest Selection on Females Is Driving Differentiation, Abstract \#668W. American Society of Human Genetics, 59th Annual Meeting, Honolulu, 20-24 October 2009.

Liu, F., Wollstein, A., Hysi, P. G., Ankra-Badu, G. A., Spector, T. D., Park, D., Zhu, G., Larsson, M., Duffy, D. L., Montgomery, G. W., Mackey, D. A., Walsh, S., Lao, O., Hofman, A., Rivadeneira, F., Vingerling, J. R., Uitterlinden, A. G., Martin, N. G., Hammond, C. J., \& Kayser, M. (2010). Digital Quantification of Human Eye Color Highlights Genetic Association of Three New Loci. PLoS Genetics, 6, e1000934. http://dx.doi.org/10.1371/journal.pgen.1000934

Maan, M. E., \& Cummings, M. E. (2009). Sexual Dimorphism and Directional Sexual Selection on Aposematic Signals in a Poison Frog. Proceedings of the National Academy of Sciences of the United States of America, 106, 19072-10977. http://dx.doi.org/10.1073/pnas.0903327106

Maanasa, R., Skoglund, P., Graf, K. E., Metspalu, M., Albrechtsen, A., Moltke, I., Rasmussen, S., Stafford Jr., T. W., Orlando, L., Metspalu, E., Karmin, M., Tambets, K., Roots, S., Mägi, R., Campos, P. F., Balanovska, E., Balanovsky, O., Khusnutdinova, E., Litvinov, S., Osipova, L. P., Fedorova, S. A., Voevoda, M. I., DeGiorgio, M., Sicheritz-Ponten, T., Brunak, S., Demeshchenko, S., Kivisild, T., Villems, R., Nielsen, R., Jakobsson, M., \& Willerslev, E. (2013). Upper Palaeolithic Siberian Genome Reveals Dual Ancestry of Native Americans. Nature, published online 20 November 2013.

Madrigal, L., \& Kelly, W. (2006). Human Skin-Color Sexual Dimorphism: A Test of the Sexual Selection Hypothesis. American Journal of Physical Anthropology, 132, 470-482. http://dx.doi.org/10.1002/ajpa.20453

Makova, K., \& Norton, H. (2005). Worldwide Polymorphism at the MC1R Locus and Normal Pigmentation Variation in Humans. Peptides, 26, 1901-1908. http://dx.doi.org/10.1016/j.peptides.2004.12.032

Manning, A. (1972). An Introduction to Animal Behaviour (2nd ed.). London: Edward Arnold.

Manning, J. T., Bundred, P. E., \& Mather, F. M. (2004). Second to Fourth Digit Ratio, Sexual Selection, and Skin Colour. Evolution and Human Behavior, 25, 38-50. http://dx.doi.org/10.1016/S1090-5138(03)00082-5

Martin, M. K. (1974). The Foraging Adaptation-Uniformity or Diversity? In Addison-Wesley Module in Anthropology, Issue 56, Boston, MA: Addison-Wesley.

Martinez-Cadenas, C., Pena-Chilet, M., Ibarrola-Villava, M., \& Ribas, G. (2013). Gender Is a Major Factor Explaining Discrepancies in Eye Colour Prediction Based on HERC2/OCA2 Genotype and the IrisPlex Model. Forensic Science International: Genetics, 7, 453-460. http://dx.doi.org/10.1016/j.fsigen.2013.03.007

Mather, F., Manning, J. T., \& Bundred, P. E. (unpublished) 2nd to 4th Digit Ratio, Hair and Eye Colour in Caucasians: Evidence for Blond Hair as a Correlate of High Prenatal Oestrogen. 
Mazess, R. B. (1967). Skin Color in Bahamian Negroes. Human Biology, 39, 145-154.

Meredith, H. V., \& Spurgeon, J. H. (1980). Somatic Comparisons at Age 9 Years for South Carolina White Girls and Girls of Other Ethnic Groups. Human Biology, 52, 401-411.

Muggleton, J. (1979). Non-Random Mating in Wild Populations of Polymorphic Adalia Bipunctata. Heredity, 42, 57-65. http://dx.doi.org/10.1038/hdy.1979.6

Nelson, J. K., \& Nelson, K. R. (1986). Skinfold Profiles of Black and White Boys and Girls Ages 11 - 13. Human Biology, 58, 379-390.

Norton, H. L., \& Hammer, M. F. (2007). Sequence Variation in the Pigmentation Candidate Gene SLC24A5 and Evidence for Independent Evolution of Light Skin in European and East Asian Populations. Program of the 77th Annual Meeting of the American Association of Physical Anthropologists, 179.

Oakley, M. (ed.) (1990). Design Management. A Handbook of Issues and Methods. Oxford: Basil Blackwell.

Olalde, I., Allentoft, M. E., Sanchez-Quinto, F., Saintpere, G., Chiang, C. W. K. et al. (2014). Derived Immune and Ancestral Pigmentation Alleles in a 7000-Year-Old Mesolithic European. Nature, early view.

Olendorf, R., Rodd, F. H., Punzalan, D., Houde, A. E., Hurt, C., Reznick, D. N., \& Hughes, K. A. (2006). Frequency-Dependent Survival in Natural Guppy Populations. Nature, 44, 633-636. http://dx.doi.org/10.1038/nature04646

Olivier, G. (1960). Pratique Anthropologique. Paris: Vigot Frères.

Rana, B. K., Hewett-Emmett, D., Jin, L., Chang, B. H. J., Sambuughin, N., Lin, M., Watkins, S., Bamshad, M., Jorde, L. B., Ramsay, M., Jenkins, T., \& Li, W. H. (1999). High Polymorphism at the Human Melanocortin 1 Receptor Locus. Genetics, $151,1547-1557$.

Ray, N., \& Adams, J. M. (2001). A GIS-Based Vegetation Map of the World at the Last Glacial Maximum (25,000-15,000 BP)-(23rd Millennium to 13th Millennium BC). Internet Archaeology, 11. http://dx.doi.org/10.11141/ia.11.2

Robins, A. H. (1991). Biological Perspectives on Human Pigmentation. Cambridge: Cambridge University Press. http://dx.doi.org/10.1017/CBO9780511600463

Russell, R. (2009). A Sex Difference in Facial Pigmentation and Its Exaggeration by Cosmetics. Perception, 38, 1211-1219. http://dx.doi.org/10.1068/p6331

Russell, R. (2010). Why Cosmetics Work. In R. Adams, N. Ambady, K. Nakayama, \& S. Shimojo (Eds.), The Science of Social Vision (pp. 186-203). New York: Oxford. http://dx.doi.org/10.1093/acprof:oso/9780195333176.003.0011

Schild, R. (1976). The Final Paleolithic Settlements of the European Plain. Scientific American, 234, 88-99. http://dx.doi.org/10.1038/scientificamerican0276-88

Shekar, S. N., Duffy, D. L., Frudakis, T., Montgomery, G. W., James, M. R., Sturm, R. A., \& Martin, N. G. (2008). Spectrophotometric Methods for Quantifying Pigmentation in Human Hair-Influence of MC1R Genotype and Environment. Photochemistry and Photobiology, 84, 719-726. http://dx.doi.org/10.1111/j.1751-1097.2007.00237.x

Simchuk, A. P. (2001). Frequency-Dependent Sexual Selection in a Natural Population of Oak Leafroller Moth (Tortrix viridana L.). Tsitologiya i Genetika, 35, 25-29.

Sinnock, P. (1970). Frequency Dependence and Mating Behavior in Tribolium castaneum. The American Naturalist, 104, 469-476. http://dx.doi.org/10.1086/282681

Soejima, M., Tachida, H., Ishida, T., Sano, A., \& Koda, Y. (2005). Evidence for Recent Positive Selection at the Human AIM1 Locus in a European Population. Molecular Biology \& Evolution, 23, 179-188. http://dx.doi.org/10.1093/molbev/msj018

Stansfield, J., \& Whitfield, T. W. A. (2005) Can Future Colour Trends Be Predicted on the Basis of Past Colour Trends? An Empirical Investigation. Color Research \& Application, 30, 235-242. http://dx.doi.org/10.1002/col.20110

Steggerda, M. (1941). Change in Hair Color with Age. Journal of Heredity, 32, 402-403.

Sturm, R. A., \& Frudakis, T. N. (2004). Eye Colour: Portals into Pigmentation Genes and Ancestry. Trends in Genetics, 20, 327-332. http://dx.doi.org/10.1016/j.tig.2004.06.010

Sturm, R. A., Duffy, D. L., Zhao, Z. Z., Leite, F. P. N., Stark, M. S., Hayward, N. K., Martin, N. G., \& Montgomery, G. W. (2008). A Single SNP in an Evolutionary Conserved Region within Intron 86 of the HERC2 Gene Determines Human Blue-Brown Eye Color. American Journal of Human Genetics, 82, 424-431. http://dx.doi.org/10.1016/j.ajhg.2007.11.005

Tarr, M. J., Kersten, D., Cheng, Y., \& Rossion, B. (2001). It’s Pat! Sexing Faces Using Only Red and Green. Journal of Vision, $1,337$.

Templeton, A. R. (2002). Out of Africa Again and Again. Nature, 416, 45-51. http://dx.doi.org/10.1038/416045a

Thelen, T. H. (1983). Minority type Human Mate Preference. Social Biology, 30, 162-180. 
van den Berghe, P. L. (1979). Human Family Systems. An Evolutionary View. New York: Elsevier.

van den Berghe, P. L., \& Frost, P. (1986). Skin Color Preference, Sexual Dimorphism and Sexual Selection: A Case of Gene-Culture Co-Evolution? Ethnic and Racial Studies, 9, 87-113. http://dx.doi.org/10.1080/01419870.1986.9993516

Voight, B. F., Kudaravalli, S., Wen, X., \& Pritchard, J. K. (2006). A Map of Recent Positive Selection in the Human Genome. PLoS Biology, 4, e72. http://dx.doi.org/10.1371/journal.pbio.0040072 